\title{
Maestro for a moment: A conceptual framework for music integration in Grade $\mathbf{R}$
}

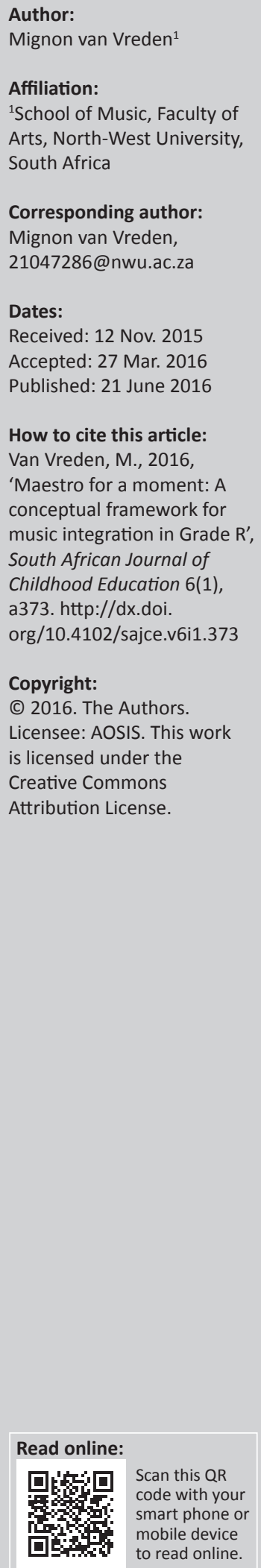

\begin{abstract}
In South Africa, possibilities to utilise music to contribute to the holistic development of preschool learners are under continuous investigation. However, music education in the Grade $\mathrm{R}$ classroom is limited due to insufficient time in the daily programme and a lack of sufficient musical training amongst generalist educators. The urgent need to equip these educators with the necessary competencies is critical. Therefore, in this article the practicability of integrating music into the daily programme in Grade $\mathrm{R}$ is explored by means of a conceptual framework. This conceptual framework was generated from the literature review and data analysis, describing six aspects of integrating music into Grade $\mathrm{R}$ teaching and learning: about music, from music, on music, with music, in music and through music. Within this framework, every aspect of integration is connected with music activities in accordance with the Grade $\mathrm{R}$ learning principles of play, exploration and practical experiences. In this article, the author argues that music can be successfully integrated into the Grade R daily programme by music specialists as well as generalist teachers with no or minimal musical training.
\end{abstract}

\section{Introduction}

In the past decade, numerous studies have explored music integration in early childhood education (Almodovar 2010; Andrews 2011; Gronski 2012) to address the issues of insufficient time for teaching music and a lack of sufficient musical training amongst generalist teachers. However, no existing studies have investigated how decreased time allocated to music education by the South African Curriculum and Assessment Policy Statement and a lack of sufficient teacher training could be addressed by music integration in Grade R.

This article discusses a multiple case study (Creswell 2007:73) with the purpose of exploring the teaching practices of five Grade R teachers in and around Potchefstroom in the North West Province and of ascertaining how they integrated music with the three Grade R subjects Home Language, Mathematics and Life Skills. In this context, music is defined as an art form integrated with the Grade R learning principles of play, exploration and practical experiences (Maritz 2011:10) in order to promote the social, physical, emotional and cognitive development of Grade R learners. The conceptual framework for music integration in Grade R that is derived from the literature review and data analysis should empower Grade $\mathrm{R}$ teachers with no or minimal musical training to apply music in their classrooms with confidence. Through this research I want to emphasise the value of music for the holistic development of Grade R learners, as music promotes intrinsic and unique qualities in learners, including the development of creativity, social skills, expression, cognition and coordination (Andrews 2011; Barrett 2001; Bresler 1994). Both researchers and practitioners in the field of music education (Campbell \& Scott-Kassner 2010; Forrai 1990; Hallam \& Creech 2010; McPherson 2006; McPherson \& Welch 2012) have unequivocally proven the value of music for the young child. The value of music for the Grade R learner supports, motivates and promotes the integration of music into the daily programme. According to Eady and Wilson (2002:24), music causes learning that is more effective. Brewer (1995:1), Campbell and Scott Kassner (2010:349) and Cane (2009:33) support this view. They emphasise that music creates a positive learning environment, atmosphere, anticipation, energises learning activities, changes the brain waves, focuses concentration, improves attention span and memory, facilitates a multisensory learning experience, relieves tension, enriches the imagination and promotes group work through the development of cooperation. Music also inspires, motivates, adds an element of fun to the learning situation, emphasises units with a specific topic, influences mood, connects disparate elements of learning and makes other forms of literacy available to everyone. Teaching music across the curriculum proposes a pedagogical approach to teaching and learning by integrating thoughts, actions and attitudes. Music integration in the daily Grade R programme can potentially enrich the lives of teachers and learners, because the effect of being surrounded by music is an enriched life (Campbell \& Scott-Kassner 2010:370). 
This study explores how music integration in Grade R could address time constraints as well as a lack of sufficient musical training.

\section{Insufficient time for music education in Grade R}

From my own experience as a music educator and my existing knowledge about the importance of music in the holistic development of learners in Grade R, I would say that the total amount of time allocated to Music as part of the subject Life Skills by the Curriculum and Assessment Policy Statement (South Africa 2011) is not sufficient. Benson (2000), Corn (1993), Curtis (2007), Purnell et al. (2007), Verkler (2003), Wheat (2005), Whitaker (1996) and Youm (2007) endorse this view. Of the 23 hours per week, two hours are set aside for Creative Arts, of which only 30 minutes is assigned to Music (South Africa 2011).

\section{Lack of sufficient musical training}

Grade $\mathrm{R}$ teachers are seldom trained music specialists and are often unsure about the implementation of music in their daily teaching. Teaching music with a positive attitude supports the development of a Grade R learner's musical skills (Kelly 1998:375), but only a few Grade R teachers use music in their teaching because of a lack of sufficient musical training, self-confidence, skills and knowledge (Mills 1989:137). A Grade R teacher's own musicianship as well as their comfort level in teaching music as a subject (Siebenaler 2006:19) often determine their effectiveness in teaching music. At a recent workshop for music integration, a group of early childhood educators in the North-West Province discussed the challenges they faced with regard to incorporating music into their Grade $\mathrm{R}$ teaching. The constraints included large classes; limited space; insufficient time for music during the daily programme; discipline problems (especially when handling musical instruments); insufficient musical instruments, CDs and props (such as scarves and ribbons for movement); lack of availability of relevant music for movement activities; difficulty in locating musical resources (for example sheet music and recordings); and a shortage of songs suitable for preschoolers. Educators struggle to get learners' attention (which leads to discipline problems) and find it difficult to combine actions with music (inadequate skills and resources). They also feel that they do not possess enough musical knowledge and are not inspired with new, creative ideas to make music lessons fun and exciting for the preschoolers. They do not always know how to integrate music throughout the day and not everyone has the self-confidence to teach music themselves. RussellBowie (2009b:23) identified similar challenges in her research in five countries, including South Africa. These include a lack of personal musical skills and experience, prioritising music as a subject, time for preparation and consolidation of musical knowledge according to the specifications of the curriculum. Russell-Bowie (2009b:34) claims that if Grade R teachers were to develop more self-confidence and skills in relation to their own musical learning and music making, they might teach music with greater success. Siebenaler
(2006:17) determined that teachers have more self-confidence in integrating music when they regularly apply musical activities in the daily programme, for example singing games, singing, movement activities, selecting songs, music listening and music notation. According to Hackett and Lindeman (2004:83), Grade R teachers can play a significant role in successfully integrating music with the daily programme, as they know the curriculum, their learners (including their cultural backgrounds) and what the most suitable time would be for teaching music. Grade R teachers are thus in a position to plan music activities that learners would enjoy before introducing new content, because they know the learners in their classes (Campbell \& Scott-Kassner 2010:347).

Research questions were derived from the two issues discussed in the preceding sections, namely insufficient time for music education in Grade $\mathrm{R}$ and a lack of sufficient musical training, to determine the boundaries of my research (Trafford \& Leshem 2008:177).

The main research question that will be explored throughout this article is as follows.

\section{Which conceptual framework explains how music could be integrated in Grade $R$ ?}

The subquestions in relation to music in Grade $\mathrm{R}$ in selected schools that guided this research are as follows.

\section{How is music integration in Grade $\mathrm{R}$ described in the literature?}

According to Boote and Beile (2005:3), a thorough, substantive, sophisticated literature review is the foundation and inspiration for substantial, useful education research. To be useful and meaningful, this type of research must be cumulative, build on and learn from prior research and scholarship on a topic. The literature review for this research was extensive (Van Vreden 2014) but due to a lack of space, it cannot be described in full in this article. The literature review described the current trends related to music integration in Grade R. In this research, a theoretical orientation (Merriam 2009:64) was extracted from the literature review based on recommendations by Merriam (2009:66) when determining the disciplinary orientation, in this case music education. Theories about learning and teaching strategies, curriculum and integration models for music laid the foundation for data collection. The original development of an integrated literature review was a technique not only to facilitate data collection, but also to determine the level of transferability of the findings (Yin 2009:38). The goal of a theoretical orientation is analytic transferability, one of the four tests for validity (Yin 2009:40). The discussion of the conceptual framework in the last section of this article includes a short summary on music integration as described in the literature. In this article, the theoretical orientation has been integrated with the findings from the data analysis in the development of the conceptual framework. 


\section{Which research method was used to generate a conceptual framework?}

The section on research design in this article will discuss the research method of the study.

\section{What are the themes that emerged from the data analysis of music in Grade R?}

According to Trafford and Lesham (2008:172), the conceptual conclusions are the most critical, since they demonstrate the relationship and relevance of one's research to other, external, research and extant theories.

\section{Research design}

The research approach for this multiple case study was qualitative in an interpretivist paradigm. The four phases of this multiple case study, based on Rule and John's dialogical approach (2011:99) and Yin's linear, iterative approach (2009:1) are illustrated in Figure 1.

For the purpose of this study, teaching and learning in five multicultural Grade R classes were explored through data collection in order to introduce and describe the cases. Data collection included observation of teaching and learning in five multicultural Grade $\mathrm{R}$ classes in the Potchefstroom region to document the ways in which music is being integrated into the classroom. The data were then organised and categorised to execute a cross-case analysis. Table 1 summarises each case in the multiple case study.

The cases with the most learning potential were selected, in order to understand, explore and gain insight into music integration in specific Grade R classes (Merriam 2009:266). The selection criteria reflected the purpose of this study and enabled the researcher to select cases with a range of

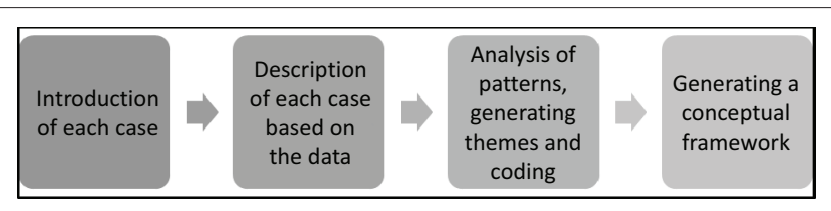

Source: Rule, P. \& John, V., 2011, Your guide to case study research, 1st edn., Van Schaik, Pretoria, p. 1

FIGURE 1: Combined research approach.

TABLE 1: Description of cases in the multiple case study.

\begin{tabular}{|c|c|c|c|}
\hline $\begin{array}{l}\text { Grade } \mathbf{R} \\
\text { class }\end{array}$ & $\begin{array}{l}\text { Instructional } \\
\text { language }\end{array}$ & $\begin{array}{l}\text { Multicultural } \\
\text { composition of learners }\end{array}$ & Location \\
\hline A & Afrikaans & $\begin{array}{l}\text { Indigenous African } \\
\text { cultures and Coloured } \\
\text { learners }\end{array}$ & Informal settlement \\
\hline \multirow[t]{2}{*}{ B } & Afrikaans & Coloured learners & Middle-class suburb \\
\hline & - & Caucasian learners & - \\
\hline C & English & $\begin{array}{l}\text { Indigenous African } \\
\text { cultures }\end{array}$ & Central business district \\
\hline \multirow[t]{2}{*}{$\mathrm{D} \dagger$} & Afrikaans & Coloured learners & Outskirts of town \\
\hline & - & Caucasian learners & - \\
\hline$E$ & English & $\begin{array}{l}\text { Indian, Portuguese and } \\
\text { indigenous African } \\
\text { learners }\end{array}$ & Outskirts of town \\
\hline
\end{tabular}

Source: Van Vreden, M., 2014, 'Musiekintegrasie in graad R:'n teoretiese raamwerk gebasee op'n gevallestudie', PhD Proefskrif, NWU, Potchefstroom, p. 61

$\dagger$, Grade $R$ classes $D$ and $E$ operated in isolation, but were part of the same preschool. possibilities to collect information. The selection criteria determined that each class should be:

- A Grade R class.

- Multicultural. ${ }^{1}$

- Taught in a language I can understand.

- In the vicinity of Potchefstroom, but located in different areas.

- Facilitated by a teacher who uses the CAPS as the foundation for teaching.

- Representative of different socio-economic circumstances.

As this research involved human subjects, ethical approval was required and granted by the Ethics Committee of the North-West University's Department of Research Support. Research was carried out with an ethical consciousness that contributed to the credibility and reliability of the study.

For each case, the data collection cycle consisted of five phases: entrance to the research terrain, access to the Grade R classroom, strategic data collection, generation and documentation of data and data preservation. The duration of data collection was 6 months. For each of the five classes I attended a complete school day for every day of the week to observe their daily programme. Semi-structured interviews were conducted with the generalist teachers, physical artefacts and documents in all classes were studied, and audio and visual material were consolidated and stored. Multiple sources of information to describe the relevant themes included observations, interviews, audio-visual material, documents and reports (Creswell 2007:73). To analyse the data, each of the five Grade $\mathrm{R}$ classes was described in detail with themes related to each description. Subsequently, each individual analysis was followed by a cross-case analysis of the individual cases and the researcher's interpretation of each case (Merriam 2009:75). Qualitative data analysis was preceded by the organisation of the data through ATLAS.ti 7.1.6, computer-assisted qualitative data analysis software, to categorise and code large amounts of narrative data from interviews and other information sources (Friese 2012). Data analysis and data collection took place simultaneously, therefore making it easier to determine data saturation. According to Merriam (2009:183), data saturation occurs when no new categories, information or knowledge are found. During data analysis, the data were organised in chronological order or according to themes and presented in a descriptive narrative. Afterwards, I described and interpreted the data in part. Eventually a conceptual framework was generated by relating the themes from the data analysis with approaches to integration as described in the literature. The goals and design of this study were based on a theoretical orientation that reflected the research questions, literature review and new orientations. This orientation was implemented to filter the data. The first step in data analysis was to identify aspects of the data relevant for the research questions. Each aspect resembled a data unit as a potential answer on the research questions. Lincoln and Guba 1.For the purpose of this article, multicultural is defined as "learners from several cultural or ethnic groups within a Grade R classroom'. 
(1985:345) describe two prerequisites for a data unit: (1) The unit must be heuristic, containing information relevant to the study that promotes thinking. (2) Each unit must be independently interpreted inside the research context. Findings were verified through long-term observation and member checking.

The combined research approach described above was used to generate a conceptual framework. The conceptual framework derived from the themes that emerged from the data analysis of music in Grade R (subquestion 3) and the music integration in Grade $\mathrm{R}$ as described in the literature (subquestion 1) explain how music could be integrated in Grade R (main research question). The discussion of the conceptual framework also describes practical methods to enrich the experiences of Grade R learners through teaching and learning.

\section{A conceptual framework for music integration in Grade $\mathbf{R}$}

Various terms in the scholarly literature are used to refer to integration (Russell \& Zembylas 2007:289). Related synonymous and descriptive terms include collaborative, cross-disciplinary, blended, interdisciplinary, intradisciplinary, multidisciplinary, transdisciplinary, holistic, thematic and embedded. Integration in African education is contextualised in order to reflect on the nature of integration in the classroom (Addo, Miya \& Potgieter 2003:236). Mans (1997:2) describes how music and dance in traditional African communities are used as teaching and learning tools for developing life skills (such as hunting), rituals, political sensitising and social skills. Traditional teaching methods consisted of observation, imitation, training, experimenting and verbal instruction. In current African educational systems, observation, imitation and training remain the foundations of education. Because traditional and modern teaching methods are closely related, Mans (1997:2) emphasises the importance of adapting traditional methods in modern teaching practices through integration. Flolu and Amuah (2003:95) describe this approach as a musically integrated approach, where ethnic cultural practices could be integrated with creative teaching in music education.

Characteristics of successful music integration include the following:

- Defined activities, expectations and outcomes that are purposefully taught.

- Learners who know their responsibilities, their working habits and their well-defined, focused and active roles in the integration process.

- Clear correspondence between learner participation and teacher facilitation (DeMoss \& Morris 2002:7).

- Contents that adhere to the requirements of integrated as well as discipline-based teaching. This implies that the contents of one subject do not overshadow those of another, lessons are practical and intellectually well founded (Burnaford 1993:45) and the relations between subjects lead to meaningful learning (Bohannon \& McDowell 2010:29).

- Musical concepts that are actively implemented to enrich and explore the contents of other subjects.

Music is part of a Grade R learner's lived experiences and should therefore be included in their daily activities at school and not only taught as an isolated subject once a week (Grobler 1987:11). Campbell and Scott-Kassner (2010:4) describe how learners utilise music as a tool for expression to socialise, to play and to move rhythmically. These skills are expanded when music is integrated with other subjects. An integrated approach to teaching promotes holistic education, with equal importance of fragmentation of subjects and intellectual knowledge as educational goals. Grade R learners and teachers experience learning as intellectually and emotionally stimulating when music is integrated into the curriculum, because integrated learning promotes creativity (Russell \& Zembylas 2007:289).

Russell-Bowie (2009a:257) warns against initiating meaningless activities without depth when music is not integrated in a meaningful way. Campbell and Scott-Kassner (2010:362) point out that a teacher's knowledge about the nature of music determines the level of integration with integrity. They emphasise that Grade $\mathrm{R}$ teachers with little or no musical training should regularly reflect on ways to develop their learners' musicality when planning integrated activities. In this way the musical value of these activities could be determined. The purpose of a conceptual framework for music integration in Grade $\mathrm{R}$ is to describe how music as an art form can be taught with integrity when a teacher is adaptable with respect to the context, while it is not necessary to change the contents (Cane 2009:38). May (2012:6) emphasises how integrated lessons must address the contents and goals of both subjects involved.

As far as music integration is concerned, current trends in the literature focus primarily on teaching, with the exception of the Learning through the Arts ${ }^{2}$ approach, where learning is central. The angle from which the data were analysed in this research focused on learning possibilities through music integration. Therefore, the conceptual framework describes music integration by combining teaching and learning as a foundation for the development of a Grade $\mathrm{R}$ learner. Teaching and learning in music should be child-centred and build upon the learners' own frame of reference - the experiences of a Grade R learner specifically, in this case (Jeanneret \& DeGraffenreid 2012:402).

Elliott (1995:12) describes the four basic meanings of the term music education directly applicable to integration: teaching in music, teaching about music, teaching for music and teaching through music. The Musikkindergarten Berlin was established in 2005 by pianist and conductor Daniel Barenboim. It is a preschool where music is not only a sporadic addition to

2.Learning through the Arts is a programme that takes responsibility for supplying teaching materials, additional help with programme coordination, programme teaching materials, additional help with programme coordination, programme Russell \& Zembylas, 2007:292). 
teaching, but is used as the central teaching medium for every child on a daily basis (Uibel 2012:51). The method in this context is not only teaching in or with music, but also through music and for music. Bresler (1995) identified four ways of integrating music in the classroom: subservient integration, social integration, co-equal integration and affective integration. Russell-Bowie's three models for integration are symmetric correlations, service connections and syntegration (2009c). In the literature study, the relations between music and teaching as described by Elliott, Bresler, Uibel and Russell-Bowie were applied to explore an integrated literature review for music integration in Grade R.

Musical experiences in preschool include singing; experimenting with tempo, volume and different sounds; developing creativity (through singing and movement); the introduction, correct handling and playing of basic percussion instruments; learning about musical concepts that relate to aural perceptual skills and cognitive development (including pitch, tempo and articulation); developing aural discrimination skills, coordination, concentration; practising listening skills in different genres (Campbell \& Scott-Kassner 2014); using music as a social-emotional therapeutic resource (Janse van Rensburg 2011:1); and supporting and strengthening the teaching of other core foundation phase subjects (South Africa 2011:8).

Figure 2 illustrates the conceptual framework that explains how music could be integrated in Grade R. As illustrated by the two-way arrows, the constant interaction between various activities emphasises the blending of simultaneous methods of integration, while the development of Grade $\mathrm{R}$ learners is promoted through teaching and learning. This conceptual framework for music integration in Grade $\mathrm{R}$ is child-centred and builds on experiences in everyday life through teaching and learning about, from, on, with, in and through music.

The relationships between the musical activities illustrated along the outer edge of the circle indicate how these activities observed in Grade $\mathrm{R}$ classes are implemented in the classroom when integrating music into the daily programme. Musical reading and notation were the only activities I did not observe in any of the Grade R classes. Nevertheless, there are many possibilities for the development of musical reading and notation in early childhood, including graphic notation (McLachlan 1980), Kodály's principles for music literacy (Jacobi 2011), creative notation inspired by musical free play (Lau \& Grieshaber 2010) and a musical notation system on a single melodic line by means of colour (Kuo \& Chuang 2013). Mills (2009) proposes that learners should be assisted to understand and expand their musical repertoire through active listening while their preferences and musical tastes are acknowledged and incorporated. Creating refers to original pieces of music or musical patterns that learners compose by themselves. These musical excerpts include melodic and rhythmic patterns. Learners enjoy opportunities to improvise and construct their own songs (Jeanneret \& DeGraffenreid 2012:405) and to react to music with an improvised accompaniment (Campbell \& Scott-Kassner 2014). Musical games and free play with music playing in the background relate to play activities. Body percussion is a movement activity connected to a listening activity (Campbell \& ScottKassner 2014:244; Jeanneret \& DeGraffenreid 2012:406). The movements of Grade R learners clearly indicate the ways they are focused on the musical elements. Movement activities are directly linked to the physical development and coordination of learners. Movement is most effective when it is not executed in isolation, but connected with listening activities, creating, singing and play (Jeanneret \& DeGraffenreid 2012:406). Sound resources for playing on instruments include musical instruments as well as soundproducing materials from the classroom and the playground, sound-producing objects from home and self-made instruments. Dramatising is a popular activity observed in Grade $\mathrm{R}$ classes. Learners also enjoy spontaneous and structured dramatising while music is playing.

Grade $\mathrm{R}$ teachers claim that singing is one of the most difficult aspects in music teaching to apply with selfconfidence, but they nevertheless use this musical activity most often (Yim, Abd-El-Fattah \& Maria Lee 2007:261). At a music workshop attended by a group of early childhood educators in the North-West Province in the winter of 2015, only a quarter of the attendees had musical training. However, all the educators integrated singing in their daily programme. More than half of these teachers were very comfortable with singing in class, one of the most general preschool music activities alongside music listening, according to Bresler (1993:3).

Singing is a favourite activity in Grade $R$, whether accompanied by a CD, a musical instrument or the teacher's own voice. Grade R learners are expected to sing while they take part in the majority of musical activities. They not only sing in the classroom but also outside the classroom. From the data analysis, it became clear that they enjoyed singing with family and friends. It became evident during the observations that learners were more comfortable singing songs in their mother tongue. The self-confidence of preschoolers is enhanced when they sing on their own in a safe, supportive environment. During a dress rehearsal for a Grade R concert, I observed that whenever a teacher took part in singing activities, the enthusiasm with which the learners sang increased. Because of the importance of singing in early childhood, Grade R learners are expected to sing along to all activities related to music integration in the daily programme. Teachers apply various strategies to develop singing as part of the daily programme. To expand the singing repertoire of Grade $\mathrm{R}$ learners, one of the teachers used a singing sack, where learners drew a song title from a bag that the rest of the class could sing. Unfortunately, not enough time was spent on teaching the songs properly to the learners, as the execution of the accompanying activities was assessed and not the singing. 


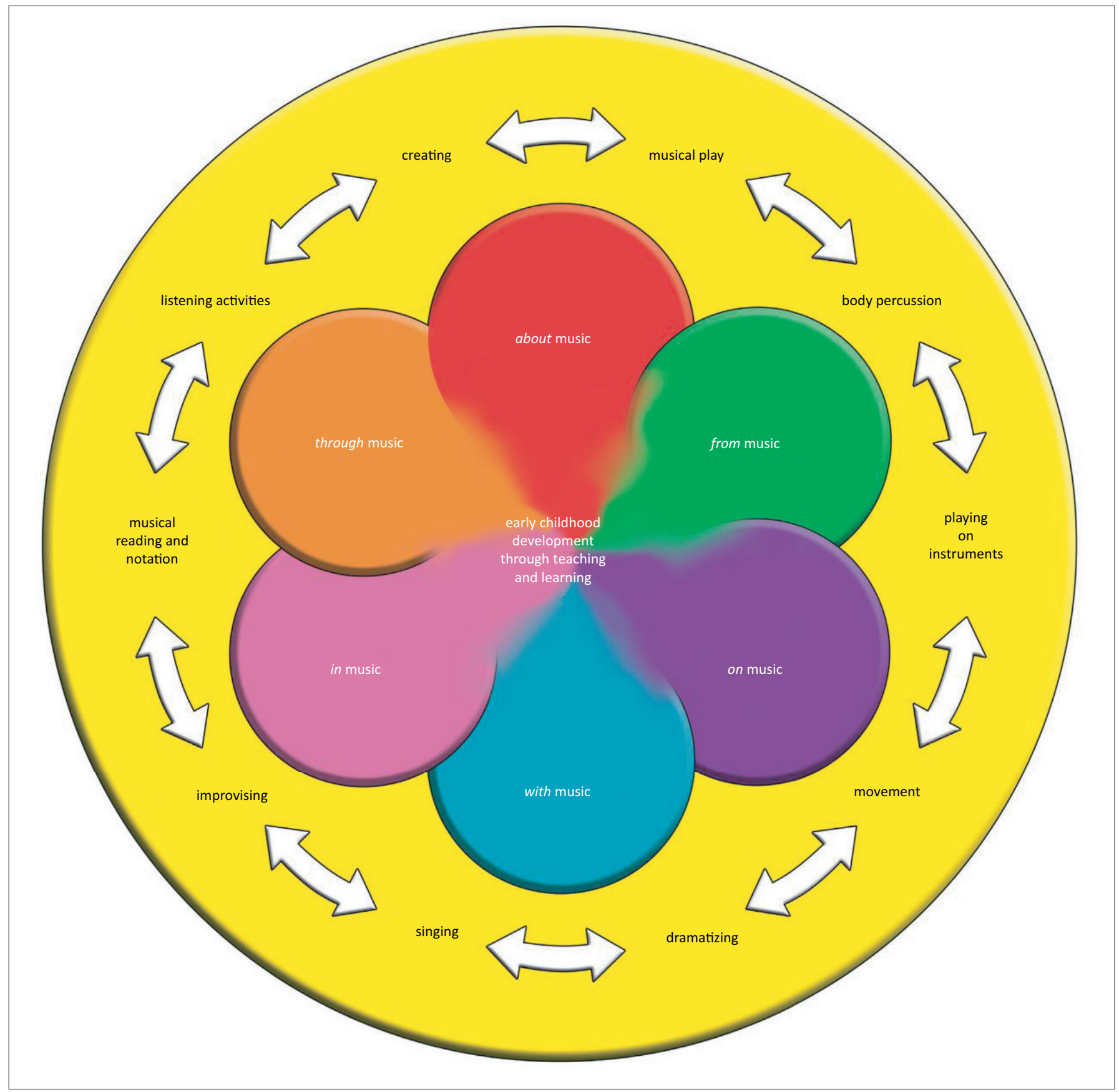

Source: Van Vreden, M., 2014, 'Musiekintegrasie in graad R: 'n teoretiese raamwerk gebaseer op'n gevallestudie', PhD Proefskrif, NWU, Potchefstroom, p. 154 FIGURE 2: A conceptual framework for music integration in Grade R.

\section{Teaching and learning about music}

From the data collection, it became evident that learning about music in Grade $\mathrm{R}$ takes place through passing on knowledge about theoretical concepts of music to learners (Elliott 1995; Gronski 2012). Music is the focus of activities. Subthemes that evolved through the data analysis of learning about music were learning about musical instruments and the elements of music, as well as exchanging thoughts about music. The aims of learning about music were to broaden musical knowledge without experiencing music as an art form or with any part of the body. A similar international trend is teaching for music (Elliott 1995:13; Uibel 2012:51), where musical content, concepts and skills such as singing are only applied to refine learners' worldview (Gronski 2012:6).

Even when teaching and learning about music occurs, it is possible that theoretical knowledge becomes musical experience by applying theoretical principles in practice. When the aim of a lesson is to teach learners about composers, a teacher could add a listening activity that focuses on specific musical instruments in the compositions of the composer and exploring the timbre (tone colour) of these instruments (Raath \& Van Vreden 2013:273). In this way learning about music is combined with learning in music and the learning experience is enhanced. Bresler (1995) refers to active integration, where music is directly embedded into the 
learning environment. Through this approach, Grade $\mathrm{R}$ learners actively or passively take part in the artistic process to enhance emotional engagement (Overland 2013:35). Rather than explaining rhythm by demonstrating a clapping pattern (learning about music), teachers should change the activity into a musical experience by having learners copy patterns and execute body percussion movements (learning in music). Music can always be taught musically when musical experiences precede theoretical knowledge and learners are comprehensively engaged.

\section{Teaching and learning in music}

Teaching and learning in music takes place when musical concepts are experienced and reinforced (Brewer 1995; Campbell \& Scott-Kassner 2014; Cane 2009; Elliott 1995; Forrai 1990; Grobler 1987; Hackett \& Lindeman 2004; Hallam \& Creech 2010; McLachlan 1986; McPherson 2006; Moog 1976; Nye 1975). Activities observed during fieldwork that were achieved by learning in music are singing, playing on instruments, body percussion, listening activities, creating music and improvisation. Music is the product and learning goal of all activities for musical development to take place when introducing musical elements to Grade $\mathrm{R}$ learners. The function of teaching and learning in music is to experience, apply and consolidate the elements of music (including dynamics, pitch, timbre, tempo, articulation, rhythm and sound duration) directly. Nationally and internationally, teaching and learning in music is often referred to as disciplinebased music education, where musical knowledge is enhanced by the practice or performance of the art form itself (Bresler 1995; Campbell \& Scott-Kassner 2014; Cane 2009; Forrai 1990; Grobler 1987; Hackett \& Lindeman 2004; Hallam \& Creech 2010; McLachlan 1986; McPherson 2006; Moog 1976; Nye 1975; Overland 2013:31).

There are many similarities between teaching and learning in music and teaching and learning on music. A complete song or recording of a piece of instrumental music can be utilised for education on music, whereas the sound produced by a musical instrument or a single note or rhythmic pattern could be a trigger for education in music. It is often unnecessary that these activities be accompanied by music, as music is the final product of the activities.

\section{Teaching and learning on music}

When activities are directly linked to musical concepts, teaching and learning on music occurs. Music determines these activities (Russell-Bowie 2009a, 2009c; Snyder 1996). Russell-Bowie (2009a:258) and Snyder (1996) use the term symmetric correlations to refer to two subjects using the same learning material to reach their individual outcomes. Musical development as well as non-musical development of skills and perceptions are promoted through teaching and learning on music in Grade R. It was observed during data collection that learning on music took place when it was determined by singing, playing on instruments, music and movement, body percussion and dramatising. For the purpose of data analysis, these musical experiences were directly linked to the elements of music and therefore categorised as learning on music. The majority of activities during data collection were performed on the beat of the music, emphasising the role of rhythm in this education strategy. Teaching and learning on music differ from teaching and learning with music, where an activity is accompanied by music but music does not determine the way in which the activity is performed. An example of dramatic free play was observed to illustrate this difference. The teacher played a recording of a song about autumn. Learners waved their arms and swayed to and fro, pretending to be trees blowing in the wind, showing how leaves fall from high up in the tree (whenever they heard high notes) all the way to the floor (when they heard low notes). In this way learners acknowledged their experience of pitch through contrasting high and low movements according to the music. Movement on music was the most popular activity in Grade $\mathrm{R}$ classes, utilising the six core aspects of movement as described by Russell-Bowie (2009a:65): action, dynamics, time, space, relationships and structure. A variety of musical elements that include structure, rhythm, metre, tempo, dynamics and pitch were experienced and developed during music and movement activities. Additional examples of how Grade R teachers addressed musical elements were collected and are described (Van Vreden 2014). To experience structure in music, the teacher played a recording of a well-known children's song. Learners lay on their backs and lifted their legs when they recognised the verses of the song and clapped their hands every time at the start of the chorus.

\section{Teaching and learning through music}

Teaching and learning through music transpires when musical activities work together in order to reach a nonmusical goal (Elliott 1995; Russell \& Zembylas 2007; RussellBowie 2009a; 2009c; Elster 2001; Snyder 1996). In this scenario, musical activities determine teaching and learning. It became obvious from the data analysis that the learning objective of learning through music is to utilise music for non-musical learning. Non-musical learning includes various experiences related to a Grade R learner's feelings, joys, existence and aspects of development including socialisation, concentration, memory, introduction and reinforcement of concepts, listening and language skills. From a South African perspective, the roles of teaching and learning through music that emerged from data analysis include enhancement of the topic of the week through songs, to create a specific atmosphere and to prevent discipline-related problems. During data collection, a safe environment was created through singing familiar songs when welcoming a few learners who visited a Grade R class when their teacher was absent. Teachers used a variety of song recordings to create a relaxing atmosphere at the end of the daily programme when learners took a nap. One Grade $\mathrm{R}$ teacher said that music motivates learners to cooperate and in this way reduces discipline problems. Another Grade R class claps a specific rhythm to signal the end of playtime, focusing learners' attention on listening to daily announcements. 
Musical development simultaneously takes place when music integration is applied with integrity. Grade $\mathrm{R}$ teachers can promote the musical integrity of learning material by making learners aware of how they use their voices to produce high and low sounds. In the literature teaching and learning through music are related to service connections, symmetric correlations (Snyder 1996) and syntegration (Russell-Bowie 2009c). The term syntegration is a combination of the words synergy and integration, referring to the possibility that the outcomes are better when combining subjects than teaching each subject on their own (Freyberger 1985:8; Gutierrez 2000:357; Russell-Bowie 2009c:7; Snyder 1996:18; Winslow 1939:32). Despite the resemblance between education through music and education with music, the difference is that music accompanies education with music, whilst a musical activity is the medium or tool for education through music.

\section{Teaching and learning with music}

Activities accompanied by music, with or without connections to musical concepts, indicate teaching and learning with music (Freyberger 1985; Russell-Bowie 2009a, 2009c; Snyder 1996; Uibel 2012; Winslow 1939). Music accompanies these activities. In terms of integration, it was clear from the data analysis that Grade $\mathrm{R}$ teachers preferred teaching and learning with music above all other themes. Related activities observed during fieldwork included dramatising, playing on instruments, listening for relaxation, play, music and movement, singing and body percussion. The objectives of learning with music that manifested from the data analysis are concert preparations, routine activities, transitional activities (including warm-up activities, closing activities and activities in between learning sessions during the daily programme), background music and socialisation. The goals of learning with music are non-musical, where the lyrics of the songs rather than the musical content determines the associated activities. Sporadically, however, even the lyrics did not have any relation to the activities. According to Uibel (2012:53), to teach with music means music as teaching tool is isolated from the learning activity. Service connections (RussellBowie 2009a; Snyder 1996) refers to a model of integration where musical learning material is used to reach an outcome in another subject, often not related to music. In my opinion, musical development is still promoted even when the goal is non-musical: when Grade $\mathrm{R}$ learners sing a song to consolidate a specific non-musical concept, referred to as piggyback songs by Cornett (2006:237), they still use their singing voices to explore and recognise different pitches. Whenever these songs are performed, unintentional musical development occurs. During music and movement activities with music, the body experiences some elements of music and incidental musical learning also takes place. One of the Grade $\mathrm{R}$ teachers shared an activity to promote the development of fine-motor skills with music where learners execute different movements with the fingers while singing a song about family. Each finger represents a different family member. When singing about a mother's kindness, learners wiggle their thumbs; when singing about a father's bravery, they wiggle their forefingers; when singing about a strong brother, they wiggle their middle fingers; when singing about the cute little sister, they wiggle their ring fingers; and when singing about the baby, they wiggle their little fingers.

The last aspect of the conceptual framework for music integration includes a vignette to substantiate a novel music integration experience that is not included in the theoretical orientation. The reason for this is that there is no literature available on this aspect of music integration, to my knowledge. Teaching and learning from music, as a new aspect of music integration observed during data collection, concludes this conceptual framework for music integration in Grade R.

\section{Teaching and learning from music}

I smile upon hearing a group of preschoolers giggling and can feel the excitement as I enter the Grade R classroom. The cause of the animated mood is a musical concert for preschoolers that the learners attended the previous day. A demonstration and explanation of musical instruments preceded the concert and clearly had an impact on one little boy. 'Come and have a look', he beckoned me. We sat down next to a creative construction of colourful blocks in different sizes laid out in a neat row on the carpet. 'Look at my marimba'!' he smiled proudly. With enthusiasm, he picked up two thin twigs and started to play on his handmade musical instrument.

The vignette above describes learning from music and narrates an event that occurred early one morning during data collection. This was the only example of learning from music in the multiple case study. I concluded that experiences related to music (in this case the tone colour of an instrument as well as the design and materials) provoked a specific thinking pattern that inspired and stimulated this young learner to apply his new knowledge to create something new: a musical instrument. This activity took place during unstructured free play, emphasising that the value of learning through play should never be underestimated. This aspect of teaching and learning, where music inspires another activity that is different from the original activity, should be explored further in Grade R through opportunities for unstructured play. Teaching and learning from music cannot always be predetermined by a specific teaching method or musical activity. Instead, teaching and learning from music often occurs spontaneously after learners have been given opportunities for unstructured play in order to explore their musical knowledge in an informal way. When this manifests, music imitates these activities. Huijsamer (2012:iv) explains the active role that preschoolers play in their own development through interactions with their environment in unstructured play. She defines this type of play as a creative expression of a preschooler's physical, cognitive, social and emotional self, where opportunities are created to acquire essential skills and values that give meaning to their existence. I therefore propose that learning from music can seldom be predetermined by a specific teaching method or musical

3.A marimba is a percussion instrument that consists of wooden bars of different sizes placed above resonators to amplify the sound when struck with mallets. The marimba is a type of idiophone but lower-pitched than the xylophone (Van Blerk 1994:255). 
activity. It is rather a reaction to teaching and learning related to music that can only surface when there is an awareness of how learners spend their time with ample opportunities for unstructured free play (Van der Linde 1999). Jeanneret and DeGraffenreid (2012:400) remark that Grade R teachers gain knowledge about their learners through their daily interactions. They propose that this knowledge should be applied to create opportunities where they can observe unprompted and continuous play to capitalise on. Therefore, a Grade $\mathrm{R}$ teacher does not always have to be a facilitator of music integration but should be receptive to unexpected moments when learners integrate music in their own learning, especially through play.

\section{Conclusion}

The main purpose of this article was to explain a conceptual framework for music integration in Grade R. This framework, which was generated from the data analysis, and the theoretical orientation, which was derived from the literature review, explore the characteristics of music integration in Grade R. Both learners and teachers with little or no musical training are enabled to experience music in a limited time frame during the daily programme through music integration. Jeanneret and De Graffenreid (2012:410) emphasise that when knowledge and self-confidence are integrated in a child-centred pedagogy, teachers become aware of the multiple ways in which learning takes place in the immediate world of every learner. The power of music to stimulate young minds and touch young hearts is never to be underestimated. Teachers will be able to utilise the aspects of music integration with confidence by selecting teaching opportunities from the conceptual framework and applying them in the daily programme, transforming every learner into a maestro for a moment.

\section{Acknowledgements Competing interests}

The author declares that she has no financial or personal relationships that may have inappropriately influenced her in writing this article.

\section{References}

Addo, A.O., Miya, F. \& Potgieter, H., 2003, 'Integrating the Arts', in A. Herbst, M. Nzewi \& K. Agawu (eds.), Musical Arts in Africa, pp. 236-260, Unisa Press, Pretoria.

Almodovar, M., 2010, 'Integrating music, drama, and the visual arts in the early childhood curriculum: A Study of Early Childhood Teachers in a Metropolitan Area of Puerto Rico', PhD Thesis, University of Massachusetts, Amherst.

Andrews, S.K., 2011, 'An examination of the integration of traditional core content areas in a Kindergarten Music Classroom: A music specialist's rationale, understandings, and perceptions', PhD Thesis, The University of Texas, Austin.

Barrett, J.R., 2001, 'Interdisciplinary work and musical integrity', Music Educators Journal 87(5), 27-31. http://dx.doi.org/10.2307/3399705

Benson, L.F., 2000, 'Using music to develop language arts skills in the classroom: A guide for the classroom teacher', PhD Thesis, Pepperdine University, Los Angeles.

Bohannon, R.L. \& McDowell, C., 2010, 'Art, music, and movement connections for elementary education teacher candidates', General Music Today 24(1), 27-31. http://dx.doi.org/10.1177/1048371310361675

Boote and Beile (2005:3), author to provide full reference details

Bresler, L., 1993, 'Music in a double-bind: Instruction by non-specialists in elementary schools', Bulletin of the Council for Research in Music Education 116, 1-13.
Bresler, L., 1995, 'Teacher knowledge: A framework and discussion', Update: Bulletin of the Council for Research in Music Education 123, 26-30.

Brewer, C.B., 1995, 'Music and learning: Integrating music in the classroom', in C.B. Brewer (ed.), Music and Learning: Seven Ways to Use Music in the Classroom, pp. 1-8, Zephyr Press, Brookline.

Burnaford, G., 1993, 'The challenges of integrated curricula', Music Educator's Journal 79(9), 44-47. http://dx.doi.org/10.2307/3398634

Campbell, P.S. \& Scott-Kassner, C., 2010, Music in Childhood: From preschool through the elementary grades, 3rd edn., Schirmer Cengage Learning, Boston.

Campbell, P.S. \& Scott-Kassner, C., 2014, Music in Childhood: From preschool through the elementary grades, 4th edn., Shirmer Cengage Learning, South Melbourne.

Cane, S., 2009, 'Collaboration with music: A noteworthy endeavor', Music Educators Journal 96(1), 33-39. http://dx.doi.org/10.1177/0027432109341165

Corn, A.E., 1993, 'Arts integration and curricular change: A case study of five first and second grades', PhD Thesis, University of Missouri, Columbia.

Cornett, C., 2006, 'Center stage: Arts-based Read-alouds', Reading Teacher (60), 234-240. http://dx.doi.org/10.1598/RT.60.3.3

Creswell, J.W., 2007, Qualitative inquiry \& research design, 2nd edn., Sage, Thousand Oaks.

Curtis, L., 2007, 'The role of music in early literacy learning: A kindergarten case study', PhD Thesis, Kansas State University, Manhattan.

DeMoss, K. \& Morris, T., 2002, How arts integration supports student learning: Students shed light on the connections, Arts Integration And Learning, viewed 16 May 2013, from http://www.capeweb.org/wp-content/uploads/2011/05/support.pdf

Eady, I. \& Wilson, J.D., 2004, 'The influence of music on core learning', Education 125(2), 243-248.

Elliott, D.J., 1995, Music matters: A new philosophy of music education, Oxford University Press, New York.

Elster, A., 2001, 'Learning through the arts: Program goals, features and pilot results', International Journal of Education and the Arts, 2(2), viewed 12 July 2006, from http://ijea.asu.edu/v2n7

Flolu, J. \& Amuah, I., 2003, An introduction to Music Education in Ghana for Universities \& Colleges, Black Mask, Accra.

Forrai, K., 1990, Music in preschool, 2nd edn., Corvina, Budapest.

Freyberger, R.M., 1985, 'Integration: Friend or foe of art education', Art education 38(6), 6-9. http://dx.doi.org/10.2307/3192869

Friese, S., 2012, Qualitative data analysis with ATLAS.ti, Sage, London.

Grobler, R., 1987, Musiek in die Pre-primêre Skool, Owen Burgess, Pinetown.

Gronski, S., 2012, 'Music integration in the kindergarten classroom: An ethnographic case study', MEd Dissertation, Fredonia, State University of New York.

Gutierrez, C., 2000, 'Making Connections. The interdisciplinary community of teaching and learning history', in P. Stearns, P. Seixas, S. Wineburg, (eds.), Knowing Teaching and Learning History: National and International Perspectives, pp. 353-374, New York University Press, New York.

Hackett, P. \& Lindeman, C.A., 2004, The musical classroom, 6th edn., Prentice-Hall, London.

Hallam, S. \& Creech, A. (eds.), 2010, Music education in the 21st Century in the United Kingdom: Achievements, analysis and aspirations, Institute of Education, London.

Huijsamer, Y., 2012. 'Ouers se persepsie van die waarde van ongestruktureerde spe vir voorskoolse kinders in die Paarl', Med Verhandeling, Noordwes-Universiteit, Potchefstroom.

Jacobi 2011, author to provide full reference details

Janse van Rensburg, O., 2011, 'Die Belangrikheid van Musiek in die Voorskoolse Jare', SAOU Preprimêr Inligtingstuk 8, 1-5.

Jeanneret, N. \& DeGraffenreid, G.M., 2012, 'Music education in the generalist classroom', in G.E. McPherson \& G.F. Welch (eds.), The Oxford Handbook of Music Education, pp. 399-416, Oxford University Press, Oxford.

Kelly, S.N., 1998, 'Preschool classroom teacher's perceptions of useful music skills and understandings', Journal of Research in Music Education 46(3), 374-383. http://dx.doi.org/10.2307/3345549

Kuo, Y. \& Chuang, M., 2013, 'A proposal of a color music notation system on a single melody for music beginners', International Journal of Music Education 31(4), 394-412. http://dx.doi.org/10.1177/0255761413489082

Lau, W.C.M. \& Grieshaber, S., 2010, 'Musical free play: A case for invented musical notation in a Hong Kong kindergarten', British Journal of Music Education 27(2), 127-140. http://dx.doi.org/10.1017/S0265051710000045

Lincoln and Guba (1985:345), author to provide full reference details

Longley, L., 1999, Gaining the Arts advantage: Lessons from School Districts that value 268 Education, viewed 03 February 2014, from http://aep-rts.org/publications/ info.htm?publication_id=12

Mans, M., 1997, Ongoma! Notes on Namibian Musical Instruments, Gamsberg Macmillan, Windhoek.

Maritz, A., 2011, The Dilemma of ECD, South African Teacher's Union, Garsfontein.

May (2012:6), author to provide full reference details

McLachlan, P., 1980, Sien wat jy hoor I \& II, Oudiovista, Goodwood.

McLachlan, P., 1986, Klasonderrig in Musiek, Nasou, Kaapstad.

McPherson, G., 2006, The child as musician: A handbook of musical development, Oxford University Press, New York. 
McPherson, G. \& Welch, G.F., 2012, The Oxford handbook of music education, Oxford University Press, New York.

Merriam, S.B., 2009, Qualitative research: A guide to design and implementation, 2nd edn., Jossey-Bass, San Francisco.

Mills, J., 1989, 'The generalist primary teacher of music: A problem of confidence', British Journal of Music Education 6(2), 125-138. http://dx.doi.org/10.1017/ S0265051700007002

Mills, J., 2009, Music in the primary school, 3rd edn., Oxford University Press, Oxford.

Moog, H., 1976, The musical experience of the preschool child, Schott, London.

Nye, V., 1975, Music for Young Children, Wm. C. Brown, lowa.

Overland, C.T., 2013, 'Integrated arts teaching: What does it mean for music education?', Music Educator's Journal 100(31), 31-37. http://dx.doi.org/ education?' Music Educator's
$10.1177 / 0027432113497762$

Purnell, P.G., Ali, P., Begum, N. \& Carter, M., 2007, 'Windows, bridges and mirrors: Building culturally responsive early childhood classrooms through the integration of literacy and the arts', Early Childhood Education Journal 34(6), 419-424 http://dx.doi.org/10.1007/s10643-007-0159-6

Raath, R. \& Van Vreden, M., 2013, Kreatiewe KABV/CAPS Graad R Tweede kwartaal, Noordwes-Universiteit, Potchefstroomkampus.

Richardson, L., 1994, 'Writing: A method of enquiry', in N.K. Denzin \& Y.S. Lincoln (eds.), Handbook of Qualitative Research, pp. 516-529, Sage, Thousand Oaks.

Rule, P. \& John, V., 2011, Your guide to case study research, 1st edn., Van Schaik, Pretoria.

Russell, J. \& Zembylas, M., 2007, 'Arts integration in the curriculum: A review of research and implications for teaching and learning', in L. Bresler (ed.), International Handbook of Research in Arts Education, pp. 287-312, Springer, New York.

Russell-Bowie, D., 2009a, Mmadd about the Arts: An Introduction to Primary Arts Education, 2nd edn., Pearson, Frenchs Forest.

Russell-Bowie, D., 2009b, 'What Me? Teach music to my primary class? Challenges to teaching music in primary schools in five countries', Music Education Research 11(1), 23-36. http://dx.doi.org/10.1080/14613800802699549

Russell-Bowie, D., 2009c, 'Syntegration or disintegration? Models of integrating the arts across the primary curriculum', International Journal of Education \& the Arts $10(28), 1-23$.
Siebenaler, D., 2006, 'Training teachers with little or no music background: Too little, too late?', Applications of Research in Music Education 24(14), 14-20. http://dx. doi.org/10.1177/87551233060240020102

Snyder, S., 1996, Integrate with Integrity, viewed 18 September 2006, from http:// www.amuse.vic.edu.au/articles.html

South Africa, 2011, Kurrikulum-en Assesseringsbeleidsverklaring Graad R-3 Lewensvaardigheid, 1ste uitg., Department of Basic Education, Pretoria.

Trafford, V. \& Leshem, S., 2008, Stepping stones to achieving your doctorate, McGrawHill, New York.

Uibel, S., 2012, 'Education through Music - The Model of the Musikkindergarten Berlin', The Neurosciences and Music 1252(1), 51-55. http://dx.doi.org/10.1111/ j.1749-6632.2011.06423.x

Van Blerk, M.E., 1994, Afrikaanse Verklarende musiekwoordeboek, Vlaeberg, Kaapstad.

Van der Linde, C.H., 1999, 'The Relationship between Play and Music in Early Childhood: Educational Insights', Education 119(4), 610-615.

Van Vreden, M., 2014, 'Musiekintegrasie in graad R: 'n teoretiese raamwerk gebaseer op'n gevallestudie', PhD Proefskrif, NWU, Potchefstroom.

Verkler, K.W., 2003, 'Idea: Simulations: Interdisciplinary Instruction at its Best', Hispania 86(2), 322-325. http://dx.doi.org/10.2307/20062866

Wheat, B.M., 2005, 'The arts-infused curriculum: A case study of art, music and drama in an exemplary elementary school', PhD Thesis, The University of Texas, Austin.

Whitaker, N.L., 1996, 'Elusive connections: Music integration and the elementary classroom', Update: Bulletin of the Council for Research in Music Education 130, 89-99.

Winslow, L.L., 1939, The integrated school art program, McGraw Hill, New York.

Yim, H.Y.B., Abd-El-Fattah, S. \& Maria Lee, L.W., 2007, 'A rasch analysis of the teachers music confidence scale', International Education Journal 8(2), 260-269.

Yin, R.K., 2009, Case Study Research, 4th edn., Sage, Los Angeles.

Youm, H., 2007, 'Processes used by music, visual Arts, media, and first-grade classroom teachers for developing and implementing an integrated curriculum: A case study', Update: Applications of Research in Music Education 26(1), 41-52. http:// dx.doi.org/10.1177/87551233070260010105 